\title{
Yield response of wheat to sorghum extract and herbicide (affinity) application at different growth
}

\author{
Afza Tabassum ${ }^{*}$, Shad Khan Khalil ${ }^{1}$, Ziaur Rahman ${ }^{2}$, Misbahullah $^{1}$, \\ Madeeha Alamzeb ${ }^{1}$, Tariq Shah ${ }^{1}$, Sajid Khan ${ }^{1}$, Tauheed ${ }^{3}$ and Hamdan \\ $\mathrm{Ali}^{1}$ \\ 1. Department of Agronomy, The University of Agriculture Peshawar-Pakistan \\ 2. Department of Agriculture, The University of Swabi-Pakistan \\ 3. Department of Food science and Technology, The University of Agriculture Peshawar-Pakistan \\ *Corresponding author's email: rayan@aup.edu.pk \\ Citation \\ AfzaTabassum, Shad Khan Khalil, Ziaur Rahman, Misbahullah, Madeeha Alamzeb, Tariq Shah, Sajid Khan, \\ Tauheed and Hamdan Ali. Yield response of wheat to sorghum extract and herbicide (affinity) application at \\ different growth. Pure and Applied Biology. Vol. 7, Issue 1, pp184-193. \\ http://dx.doi.org/10.19045/bspab.2018.70022
}

\begin{tabular}{llll}
\hline \hline Received: $30 / 10 / 2017$ & Revised: 04/01/2018 & Accepted: 24/01/2018 & Online First: 28/01/2018 \\
\hline \hline
\end{tabular}

\section{Abstract}

Allelopathic water extracts are the solutionsthat are obtained from the allelopathic crops like sorghum, sunflower and brassica which have the potential to control weeds, especially when applied in combination with reduced rates of herbicides. Aim of this experiment was to study the effectiveness of herbicide, sorghum extract and their application times on weed dynamics and yield of wheat. Sorghum extract with three concentrations $(1: 3,1: 4,1: 5)$, herbicide (affinity) with three different levels $(1 / 3,1 / 2,2 / 3$ of the recommended dose) and along with three application time (emergence, tillering, 50\% at tillering time and 50\% at emergence time) were applied. Herbicide sole, un-weeded and weeded plots were considered for comparative study. Among all the treatments, herbicide sole had higher effect followed by hand-weeded plots for minimizing weeds density, weed dry weight, fresh weight and increased grain yield and yield contributing constitutes of wheat. Sorghum application time and sorghum extract concentration considerably increased yield and yield components and decreased weed density in wheat. Sorghum extracts spurted at 1:5 gave more grain spike ${ }^{-1}(45)$, increased spike $\mathrm{m}^{-2}(257)$, high thousand grain weight $(59.0 \mathrm{~g})$ and higher harvest index $(36.8 \%)$, while taller plants were noted with 1:4 (92.4 $\mathrm{cm})$. Herbicide (affinity) at the rate of $1317 \mathrm{~g} \mathrm{ha}^{-1}$ resulted in significantly increased spike $\mathrm{m}^{-2}(256)$, increased grain spike ${ }^{-1}(45)$, higher thousand grain weight (58.3 g), and higher harvest index (37.4\%), Sorghum extract concentration with combination of herbicide sprayed at tillering stage gave more spike $\mathrm{m}^{-2}$ (255), increased grain spike ${ }^{-1}(44.8)$, while more harvest index $(36.4 \%)$ were found when treatments applied $50 \%$ at emergence $+50 \%$ at tillering or tillering stage. Thousand grain weight were found non-significant. It is concluded that sorghum extract concentration $1: 5$ with $1317 \mathrm{~g} \mathrm{ha}^{-1}$ of herbicide affinity used at tillering stage is proposed for effective weeds control, high yield and high net return of wheat crop.

Keywords: Allelopathy; Affinity; Harvest index; Sorghum extract; Wheat

\section{Introduction}

In Pakistan, weeds create huge problems during production of crops because weed control is not given proper preference due to the financial status of our farmers and the absence of education. Non progressive farmers have not enough money to meet the asking price of weed management requirements carry out for the production of crops. Thus this is due to weeds that growing among crop plants and adversely affect yield and quality of the harvest and maximize 
production costs, with low income returns. Among weeds some of them cause serious problems to crop plants and compete for various resources for example nutrients, moisture, sunlight and space [1]. Apart from competition, many other factors like lodging and harvesting problems are created by weeds. In Pakistan, weeds are accountable for 30 percent grain yield losses in wheat which amounts to Rs. 1150 million annually [2]. Weed decline yield and quality of crop plants and leads to higher cost in food production [3]. Therefore, weed control is one of the most important aspects of crop production in agricultural systems.

For better yield weed management is very crucial factor. The type of weed control which is traditional have some flaws which include time consumption, intense labor and dependency on weather. Unnecessary use of herbicide is expensive and causes environmental problems [4] and it has also adverse effects on the nutritive value of several crops [5].Besides this, research has proved herbicides resistant weeds [6] in areas to the unnecessary and too much usage of herbicides.

Allelopathy is an inexpensive, natural, environment friendly and an organic attitude to regulate weed density and proliferate crop yields as it conserve the ecosystem [7] concluded that sorghum plant is extremely allelopathic and sorghum remains could be significantly used to accomplish several vital weeds in irrigated wheat crop with no effect on the main crop in semi-arid conditions. Mature sorghum plants possess nine water soluble chemicals which are phytotoxic to certain weeds such as Phalaris minor Retz. Chenopodium album L., Rumex dentatus L., and Convolvulus arvensis L. [8, 9] used water extracts of ripened sorghum plants and described that water extract spray minimized biomass of weed from 35 to $40 \%$ and proliferated yield of wheat from 10 to $20 \%$. Researchers have also reported that the allelochemicals production in plants is affected by numerous factors related to environment and increased amount of allelochemicals have been reported in plants developed under mineral stress and drought $[10,11]$.

Allelo-chemicals, which have the ability to exterminate some species of plants, are considered highly as these substances have the potential of working as naturally selective herbicide [12].Cultivars which are highly suppressed by weeds need allelopathic crops for their substantial development [6]. Sunflowers have allelopathic properties which are published many times and this crop is famous for their herbicidal effect on numerous crops and weeds. Different sunflowers cultivars were selected by [13].and extracted 125 different allelopathic compounds which were phytotoxic for various plants.[14, 15]also reported that seed germination of white mustard (Sinapis alba L.) was fully inhibited by the extracts of sunflower, while it had no effect on the viability of seeds [15].

\section{Materials and methods}

Effect of sorghum extract concentration in combination with herbicide application times on weed density and yield of wheat was evaluated at Agronomy Research Farm, The University of Agriculture Peshawar, Pakistan during 2015-16. The experiment was laid out in a randomized complete block design (RCBD) having three replications. A plot size of $3 \mathrm{~m} \times 1.8 \mathrm{~m}$ (L x W) was used. Each plot consists of six rows having $30 \mathrm{~cm}$ row to row distance. Wheat variety (Atta Habib 2010) at the seed rate of $120 \mathrm{Kg} \mathrm{ha}^{-1}$ was sown on 21 November 2015 with the help of seed drill, and harvested on 12 May 2016 by hand sickle. Nitrogen and phosphorous fertilizers were applied at the rate of $120-90 \mathrm{~kg} \mathrm{ha}^{-1}$ respectively, and source of $\mathrm{N}$ and $\mathrm{P}$ fertilizer were applied in the form of urea $(46 \% \mathrm{~N})$ and diammonium phosphate $\left(46 \% \mathrm{P}_{2} \mathrm{O}_{5}\right.$ and $\left.18 \% \mathrm{~N}\right)$. All phosphorous fertilizer and half of nitrogen were applied at the time of sowing; remaining nitrogen was applied at first irrigation. Irrigation was applied whenever required. Three factors and their levels were studied in the experiment which included: 


\section{Factor-A: Concentration $(C)$}

$\begin{array}{llll}\mathrm{C} 1 & = & 1: 3 & \text { (1 kg sorghum plant herbage }+3 \text { liters of water) } \\ \mathrm{C} 2 & = & 1: 4 & \text { (1 kg sorghum plant herbage+4 liters of water) } \\ \mathrm{C} 3 & = & 1: 5 & \text { (1 kg sorghum plant herbage }+5 \text { liters of water) }\end{array}$

Factor-B: Herbicide ratio (HR)

$\begin{array}{lll}\mathrm{R} 1 & = & 1 / 3 \text { of the recommended dose of Affinity } \\ \mathrm{R} 2 & = & 1 / 2 \text { of the recommended dose of Affinity } \\ \mathrm{R} 3 & = & 2 / 3 \text { of the recommended dose of Affinity }\end{array}$

Factor-C: Application time (AT)

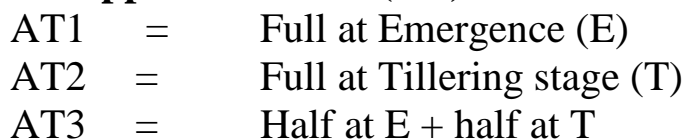

All three factors were applied in following combinations:

Different concentration (1:3) i.e. $(1 \mathrm{~kg}$ sorghum and 3 liters of water), (1:4) i.e. (1 $\mathrm{kg}$ sorghum and 4 liters of water) and (1:5) i.e. (1 kg sorghum and 5 liters of water) of sorghum extract were sprayed at three stages full at emergence, full at tillering and half at emergence plus half at tillering. Experiment were also include Control (no weed control), hand weeding (HW) and herbicides application. Herbicide "Affinity" (post emergence herbicide) was applied at three different ratios i.e. one third (1/3) of the recommended dose $\left(670 \mathrm{~g} \mathrm{ha}^{-1}\right)$, half (1/2) of the recommended dose $\left(988 \mathrm{~g} \mathrm{ha}^{-1}\right)$ and two third (2/3) of the recommended dose (1317 $\left.\mathrm{g} \mathrm{ha}^{-1}\right)$. All other agronomic practices were applied uniformly.

\section{Preparation of sorghum herbage water extract}

Mature plant herbage of sorghum was collected from New Developmental Farm, The University of Agriculture Peshawar,
Pakistan and was used in water extract preparation for field experiment. For making sorghum water extract, the sun dried sorghum herbage were chopped into $2-4 \mathrm{~cm}$ pieces with electric fodder cutting machine. Then soaked in 9 liter tubs for 48 hours by maintaining (1:3) i.e.(1 kg plant herbage and 3 liters of water), (1:4) i.e. (1 kg plant herbage and 4 liters of water), (1:5) i.e. (1 kg plant herbage and 5 liters of water) for preparation of different concentrations. Then the mixture (sorghum herbage and water) was sieved by muslin cloth and obtain extract of sorghum to remove sorghum crop herbage.Data were recorded by using standard methods according to Spikes $\mathrm{m}^{-2}$, Grains spike ${ }^{-1}$, thousand grains weight, Harvest index and Economical analysis. For obtaining data on Spike $\mathrm{m}^{-2}$ the number of spike in one meter at two various points were measured in 2 rows at the center in each plot and then conversion was done to the number of spike $\mathrm{m}^{-2}$.

Spikes $\mathrm{m}^{-2}=$

Number of spikes in a meter row

Number of rows (2) x r-r distance $(0.3 \mathrm{~m})$ x row length $(1 \mathrm{~m})$

For the determination of grains spike $^{-1}$ ten spikes were chosen in each plot and grains were calculated. After this process, the final data was recorded on average basis. Thousand grain weight data was recorded by taking sample of thousand grains from threshed grain of each plot and then weighed with a digital balance to calculate weight of thousand grains. Harvest index was calculated for each plot dividing grain yield on biological yield and then multiplied with 100 to get harvest index in percentage. 
Harvest index $(\%)=\frac{\text { Economic yield }\left(\mathrm{kg} \mathrm{ha}^{-1}\right)}{\text { Biological yield }\left(\mathrm{kg} \mathrm{ha}^{-1}\right)} \times 100$

Economic analysis were carried out by calculating marginal rate of return (MMR) as done by [16]. To determine (MMR) total cost of treatment first and second, net benefits of the treatment first and second and their difference were calculated and then multiplied with 100 as in the formula given below. Similar process was repeated for all other treatments.

$\mathrm{MMR}=\frac{\text { Difference between benefits of }(\mathrm{T} 2-\mathrm{T} 1) \times 100}{\text { Difference between cost of }(\mathrm{T} 2-\mathrm{T} 1)}$

\section{Statistical Analysis}

All the data recorded were evaluated statistically through analysis of variance methods suitable for RCBD (randomized complete block design). Means were compared by using LSD test at 0.05 (level) of probability whenever the F-values were found significant [17].

\section{Results and discussion \\ Spikes $\mathbf{~ m}^{-2}$}

Data concerning spike $\mathrm{m}^{-2}$ was significantly influenced by sorghum concentration (SC), affinity ratio (AR), application time (AT), $\mathrm{R} \times \mathrm{T}, \mathrm{C} \times \mathrm{R}$,controlvs rest, hand weeding vs herbicide, while herbicide sole, $\mathrm{C} x \mathrm{~T}, \mathrm{C}$ $\mathrm{x} R \times \mathrm{T}$, interaction were found nonsignificant (Table 1). Spike $\mathrm{m}^{-2}$ increased with decreased in sorghum concentration and maximum spike $\mathrm{m}^{-2}$ was obtained from 1:5 sorghum concentration while less spike $\mathrm{m}^{-2}$ were obtained from higher sorghum concentration 1:3. Lower dose of herbicide affinity $(670 \mathrm{~g})$ produced less spike $\mathrm{m}^{-2}$. Higher affinity ratios $(1317 \mathrm{~g})$ resulted in maximum spike $\mathrm{m}^{-2}$ which was statistically at par with affinity ratio $(988 \mathrm{~g})$. Mean values of the application time showed that sorghum herbage applied at tillering stage produced maximum spike $\mathrm{m}^{-2}$ which was statistically similar to sorghum herbage applied at emergence, while lower number of spike $\mathrm{m}^{-2}$ were observed when the treatments applied at $50 \%$ at $\mathrm{E}+50 \%$ at $\mathrm{T}$. The greater number of spike $\mathrm{m}^{-2}$ with hand weeded, sorghum concentration and application time could be the reason of higher phytotoxic influence of herbicide on weed, on contrast, the less no. of spike meter $^{-1}$ in control plot could be the reason of higher density of weed that increase the weed struggle with wheat crop for requirements such as water, nutrients, air etc. Similar results have also been reported by $[18,19]$. They reported substantial rise in spike $\mathrm{m}^{-2}$ along with the application of herbicide. These findings are in similarity with [20] where he found substantial rise in no of spikes by the application of allelopathic extracts of many plants.

\section{Grains spike ${ }^{-1}$}

Spikes latent is detrimental if considered in number of grain spike ${ }^{-1}$ and is a significant component of yield. The statistical data confirmed that grain spike ${ }^{-1}$ was significantly influenced by sorghum concentration (SC), affinity ratio (AR), application timing (AT), control vs rest, hand weeding vs herbicide, herbicide sole vs ratio, herbicide sole and $\mathrm{C} x \mathrm{R}$, while $\mathrm{R}$ $\mathrm{x}$ T, Cx T, C x R x T interaction were found non-significant (Table 2). Minimum grain spike $^{-1}$ was obtained from sorghum concentration 1:3. Maximum grain spike ${ }^{1}$ were recorded from 1:5 which was statistically at par with sorghum concentration 1:4. Less grain spike ${ }^{-1}$ were recorded from affinity applied at $(988 \mathrm{~g})$, while higher affinity ratio $(1317 \mathrm{~g})$ resulted in more grain spike ${ }^{-1}$. Sorghum herbage applied at tillering stage produced higher grain spike ${ }^{-1}$ and it was at level mathematically with that of sorghum herbage used during emerging time while the lowest grain spike ${ }^{-1}$ were obtained from 
sorghum herbage used $50 \%$ during emergence $+50 \%$ during tillering stage. Maximum grain spike ${ }^{-1}$ was obtained from hand weeded plots as compare to control and the rest of treated plot. Similarly sorghum concentration, herbicide and application time gave more grain spike ${ }^{-1}$ over control plots. The reason of increased number of grain spike ${ }^{-1}$ is attributed to the effective weed control in those treatments and the wheat crop efficiently utilized all the available resources. These results are in line with $[18,21,22]$ who reported that herbicide application significantly increased the grain spike ${ }^{-1}$. In control plots, the decrease in grain spike ${ }^{-1}$ might be of the rationale that competition between weeds and wheat crop was there for growth requirements. Similar results have been shown by $[20,23]$ where they found effectively higher grains per spike with control plots and water extracts.

Table 1.Spike $\mathrm{m}^{-2}$ of wheat as affected by sorghum water extract in combination with herbicide application timing

\begin{tabular}{|c|c|c|c|c|c|}
\hline \multirow[b]{2}{*}{$\begin{array}{c}\text { Affinity } \\
\left(1976 \mathrm{~g} \mathrm{ha}^{-1}\right)^{\dagger}\end{array}$} & \multirow{2}{*}{$\begin{array}{l}\text { concentration } \\
\text { of sorghum } \\
(\mathrm{kg}) \mathrm{L}^{-1} \text { water }\end{array}$} & \multicolumn{3}{|c|}{ Application Time } & \multirow[b]{2}{*}{ Mean } \\
\hline & & $\begin{array}{c}\text { Emergence } \\
\text { (E) }\end{array}$ & $\begin{array}{l}\text { Tillering } \\
\text { (T) }\end{array}$ & $1 / 2$ at $E+1 / 2$ at $T$ & \\
\hline \multirow[t]{3}{*}{670} & $1: 3$ & 205 & 238 & 218 & 220 \\
\hline & $1: 4$ & 222 & 247 & 238 & 236 \\
\hline & $1: 5$ & 247 & 261 & 237 & 248 \\
\hline \multirow[t]{3}{*}{988} & $1: 3$ & 262 & 252 & 213 & 242 \\
\hline & $1: 4$ & 296 & 262 & 220 & 260 \\
\hline & $1: 5$ & 257 & 258 & 242 & 252 \\
\hline \multirow[t]{3}{*}{1317} & $1: 3$ & 237 & 251 & 268 & 252 \\
\hline & $1: 4$ & 251 & 251 & 236 & 246 \\
\hline & $1: 5$ & 282 & 276 & 255 & 271 \\
\hline 670 & & 225 & 248 & 231 & $235 \mathrm{~b}$ \\
\hline 988 & & 272 & 257 & 225 & $251 \mathrm{a}$ \\
\hline \multirow[t]{4}{*}{1317} & & 257 & 259 & 253 & $256 \mathrm{a}$ \\
\hline & $1: 3$ & 235 & 247 & 233 & $238 \mathrm{~b}$ \\
\hline & $1: 4$ & 256 & 253 & 231 & $247 \mathrm{ab}$ \\
\hline & $1: 5$ & 262 & 265 & 245 & $257 \mathrm{a}$ \\
\hline Mean & & $251 \mathrm{a}$ & $255 \mathrm{a}$ & $236 \mathrm{~b}$ & \\
\hline Control & & & & & $202.44 \mathrm{~b}$ \\
\hline \multicolumn{2}{|c|}{ Rest of treatments } & & & & $247.95 \mathrm{a}$ \\
\hline Hand weeding & & & & & $278.7 \mathrm{a}$ \\
\hline Herbicide & & & & & $246.9 \mathrm{~b}$ \\
\hline Herbicide sole & & & & & $241.61 \mathrm{a}$ \\
\hline Ratio & & & & & $247.52 \mathrm{~b}$ \\
\hline
\end{tabular}

Affinity recommended dose

$\mathrm{LSD}_{0.05}$ for concentration

$\mathrm{SD}_{0.05}$ for ratio

Means within the same category followed by different letters are significantly different at $\mathrm{P} \leq 0.05$ using LSD test.

\section{Thousand grain weight (g)}

Thousand grains weight was significantly affected by sorghum concentration, affinity ratios, control vs. rest, hand weeding vs. herbicide, herbicide sole vs. ratio, $\mathrm{C} x \mathrm{R}, \mathrm{R}$ $\mathrm{x} T$ whereas, application timing, herbicide sole, $\mathrm{C} \times \mathrm{T}, \mathrm{C} \times \mathrm{R} \times \mathrm{T}$ interaction were found non-significant (Table 3). Less thousand grain weight were recorded in higher sorghum concentration 1:3 which was statistically similar with sorghum concentration 1:4. Thousand grains weight 
increased with decreasing sorghum concentration 1:5. Higher affinity ratios $(1317 \mathrm{~g})$ resulted in higher thousand grains weight which was statistically at par with affinity ratio (988 g). Lower affinity dose $(670 \mathrm{~g})$ resulted in lower thousand grain weight. Maximum thousand grains weight were recorded in hand weeded plots in comparison to control. Mean values for application time revealed that treatments applied at tillering time gave maximum thousand grain weight. Highest grain weight might be due to successful weed control in treated plots. It could be due to the action of various types of allelochemicals present in allelopathic plants that were used in the form of water extracts. Extracts of tested species might have the potential to be used for weed control [24]. [25] also reported significantly positive effects of sorghum WE spray on 1000 -grain weight. The increased grain weight could be attributed to the availability of resources to the wheat crop. Our results are in line with the finding of [26] who concluded that maximum 1000 grain weight was recorded in those plots which were treated with the mixture of herbicides, while minimum in weedy check plots. [27] also reported that herbicide treated plots gave higher 1000 grain weight than the weedy check plots.

Table 2. Grains spike ${ }^{-1}$ of wheat as affected by sorghum water extract in combination with herbicide application timing.

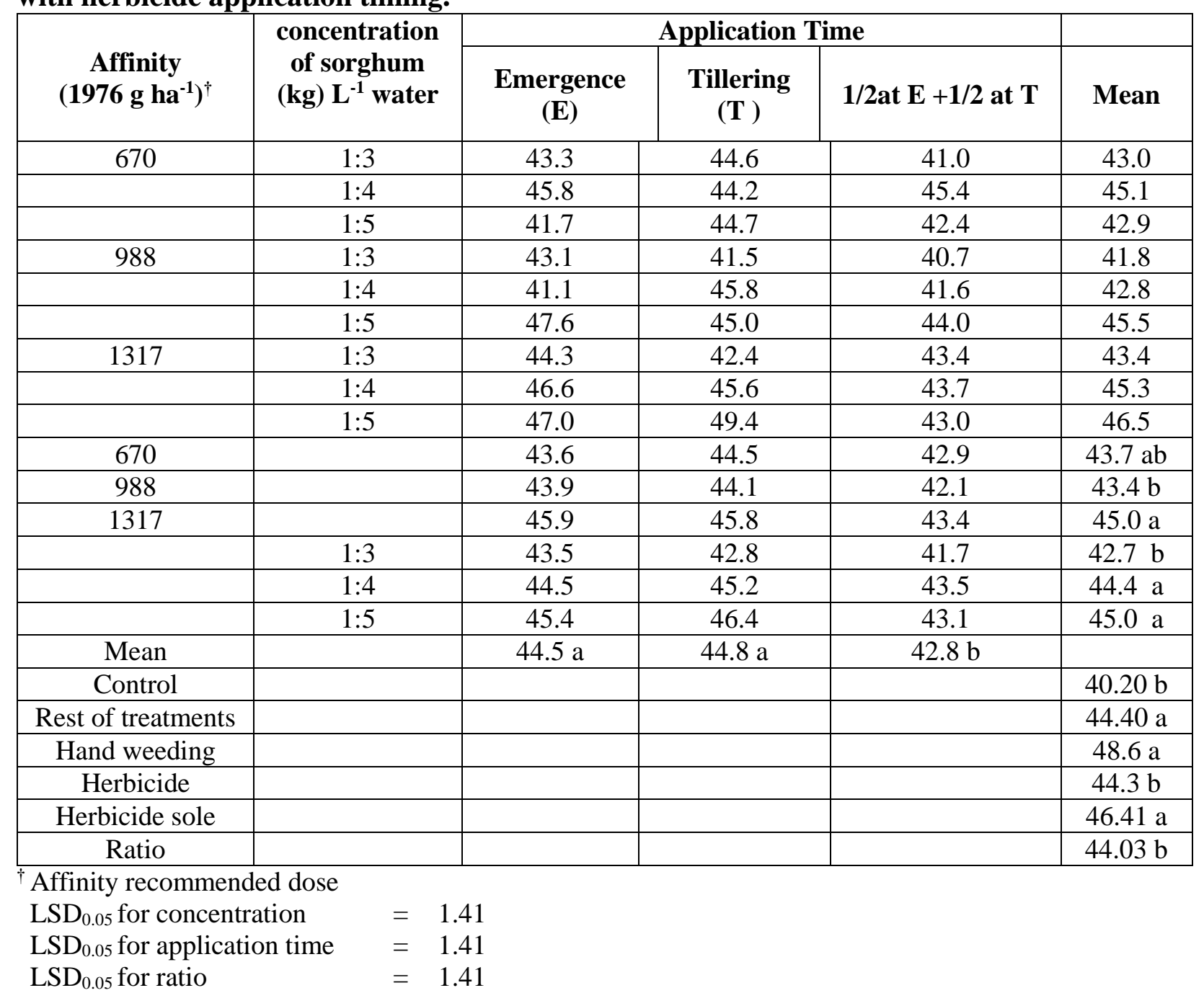

Means within the same category followed by different letters are significantly different at $\mathrm{P} \leq 0.05$ using LSD test. 


\section{Harvest index (\%)}

Sorghum concentration (SC), affinity ratio (AR), application timing (AT), herbicide sole vs. ratio and $\mathrm{R} \times \mathrm{T}$ significantly affected to harvest index whereas, control vs. rest, hand weeding vs. herbicide, herbicide sole, $\mathrm{C} \times \mathrm{R}, \mathrm{C} \times \mathrm{T}, \mathrm{C} \times \mathrm{R} \times \mathrm{T}$ interaction were found non-significant (Table 4). Maximum harvest index were recorded from 1:5. Higher affinity ratio $(1317 \mathrm{~g})$ resulted in higher grain yield. Sorghum herbage applied at tillering stage or $50 \%$ during emerging stage $+50 \%$ at tillering produced higher harvest index, while the lowest harvest index were obtained from sorghum herbage applied at emergence. The relationship between biological yield and economic yield is termed as Harvest index, for this reason, high harvest index with sorghum concentration, hand weeding, herbicide and application timing could be the reason that increased grain yield which then caused high harvest index in wheat crop. Similar findings have also been reported by $[28,29]$ where they found substantial increase in Harvest index through various concentrations of water extract that contained allelochemicals. Same findings have also been published by [20] where they found that harvest index and all other parameters were enhanced by herbicide application.

Table 3. Thousand grain weight (g) of wheat as affected by sorghum water extract in combination with herbicide application timing

\begin{tabular}{|c|c|c|c|c|c|}
\hline \multirow[b]{2}{*}{$\begin{array}{c}\text { Affinity } \\
\left(1976 \mathrm{~g} \mathrm{ha}^{-1}\right)^{\dagger}\end{array}$} & \multirow{2}{*}{$\begin{array}{l}\text { concentratio } \\
\text { n of sorghum } \\
(\mathrm{kg}) \mathbf{L}^{-1} \\
\text { water }\end{array}$} & \multicolumn{3}{|c|}{ Application Time } & \multirow[b]{2}{*}{ Mean } \\
\hline & & $\begin{array}{c}\text { Emergence } \\
\text { ( E ) }\end{array}$ & $\begin{array}{l}\text { Tillering } \\
\text { (T) }\end{array}$ & $1 / 2$ at $E+1 / 2$ at $T$ & \\
\hline \multirow[t]{3}{*}{670} & $1: 3$ & 55.63 & 56.53 & 56.43 & 56.2 \\
\hline & $1: 4$ & 55.00 & 58.03 & 58.70 & 57.2 \\
\hline & $1: 5$ & 57.70 & 57.23 & 59.13 & 58.0 \\
\hline \multirow[t]{3}{*}{988} & $1: 3$ & 58.80 & 55.63 & 59.80 & 58.1 \\
\hline & $1: 4$ & 58.93 & 57.70 & 58.27 & 58.3 \\
\hline & $1: 5$ & 59.60 & 57.60 & 58.70 & 58.6 \\
\hline \multirow[t]{3}{*}{1317} & $1: 3$ & 56.33 & 58.93 & 57.37 & 57.5 \\
\hline & $1: 4$ & 56.93 & 56.43 & 57.37 & 56.9 \\
\hline & $1: 5$ & 61.33 & 60.10 & 59.60 & 60.3 \\
\hline 670 & & 56.1 & 57.3 & 58.1 & $57.2 \mathrm{~b}$ \\
\hline 988 & & 59.1 & 57.0 & 58.9 & $58.3 \mathrm{a}$ \\
\hline \multirow{4}{*}{1317} & & 58.2 & 58.5 & 58.1 & $58.3 \mathrm{a}$ \\
\hline & $1: 3$ & 56.9 & 57.0 & 57.9 & $57.3 \mathrm{~b}$ \\
\hline & $1: 4$ & 57.0 & 57.4 & 58.1 & $57.5 \mathrm{~b}$ \\
\hline & $1: 5$ & 59.5 & 58.3 & 59.1 & $59.0 \mathrm{a}$ \\
\hline Mean & & 57.8 & 57.6 & 58.4 & \\
\hline Control & & & & & $53.83 \mathrm{~b}$ \\
\hline Rest of treatments & & & & & $57.87 \mathrm{a}$ \\
\hline Hand weeding & & & & & $60.5 \mathrm{a}$ \\
\hline Herbicide & & & & & $57.8 \mathrm{~b}$ \\
\hline Herbicide sole & & & & & 56.51 \\
\hline Ratio & & & & & 57.92 \\
\hline
\end{tabular}

Affinity recommended dose

$\mathrm{LSD}_{0.05}$ for concentration $\quad=0.98$

$\mathrm{LSD}_{0.05}$ for application time $\quad=0.98$

$\mathrm{LSD}_{0.05}$ for ratio $\quad=0.98$

Means within the same category followed by different letters are different at $\mathrm{P} \leq 0.05$ using LSD test. 


\section{Economic analysis}

Data concerning to economic analysis of various treatments studied in the experiment are presented in (Table 5). Lower VCR was observed from lower1:3sorghum extract that increase with increasing concentration. Whereas maximum net return was observed from 1:5 sorghum extract. 1:5 sorghum extract resulted in highest net return (Rs. 164244) compared with 1:3 sorghum extract (Rs.150472). $1317 \mathrm{~g} \mathrm{ha}^{-1}$ affinity dose gives maximum net return (Rs.160763) and VCR (5.3), followed by $988 \mathrm{~g} \mathrm{ha}^{-1}$, whereas minimum net return (Rs.153938) and VCR (5.2) was obtained from $670 \mathrm{~g} \mathrm{ha}^{-1}$ affinity doses. In case of application timing AT2 (tillering stage) was economical in term of net return (Rs.159404) and VCR (4.8), whereas AT3 (half at E + half at T) resulted in minimum net return (Rs.152899) and VCR (4.6). Herbicides sole resulted in minimum net return (Rs.147651) and VCR (4.9) followed by control plots (Rs.132744), while hand weeded plots resulted in maximum net return (Rs.172828) and VCR (5.5).

Table 4. Harvest index (\%) of wheat as affected by sorghum water extract in combination with herbicide application timing

\begin{tabular}{|c|c|c|c|c|c|}
\hline \multirow{2}{*}{$\begin{array}{c}\text { Affinity } \\
\left(1976 \mathrm{~g} \mathrm{ha}^{-1}\right)^{\dagger}\end{array}$} & \multirow{2}{*}{$\begin{array}{l}\text { concentration } \\
\text { of sorghum } \\
(\mathrm{kg}) \mathrm{L}^{-1} \text { water }\end{array}$} & \multicolumn{3}{|c|}{ Application Time } & \multirow[b]{2}{*}{ Mean } \\
\hline & & $\begin{array}{c}\text { Emergence } \\
\text { (E) }\end{array}$ & $\begin{array}{l}\text { Tillering } \\
\text { (T) }\end{array}$ & $1 / 2$ at $E+1 / 2$ at $T$ & \\
\hline \multirow[t]{3}{*}{670} & $1: 3$ & 34.2 & 33.7 & 36.7 & 34.9 \\
\hline & $1: 4$ & 34.5 & 32.4 & 35.4 & 34.1 \\
\hline & $1: 5$ & 35.5 & 35.5 & 37.2 & 36.0 \\
\hline \multirow[t]{3}{*}{988} & $1: 3$ & 32.5 & 34.4 & 35.8 & 34.2 \\
\hline & $1: 4$ & 32.8 & 33.7 & 35.7 & 34.1 \\
\hline & $1: 5$ & 34.8 & 38.7 & 36.6 & 36.7 \\
\hline \multirow[t]{3}{*}{1317} & $1: 3$ & 36.9 & 37.9 & 36.4 & 37.1 \\
\hline & $1: 4$ & 35.6 & 40.0 & 36.7 & 37.5 \\
\hline & $1: 5$ & 36.7 & 39.2 & 37.1 & 37.7 \\
\hline 670 & & 34.7 & 33.9 & 36.4 & $35.0 \mathrm{~b}$ \\
\hline 988 & & 33.4 & 35.6 & 36.0 & $35.0 \mathrm{~b}$ \\
\hline \multirow[t]{4}{*}{1317} & & 36.4 & 39.1 & 36.7 & $37.4 \mathrm{a}$ \\
\hline & $1: 3$ & 34.5 & 35.3 & 36.3 & $35.4 \mathrm{~b}$ \\
\hline & $1: 4$ & 34.3 & 35.4 & 35.9 & $35.2 \mathrm{~b}$ \\
\hline & $1: 5$ & 35.7 & 37.8 & 36.9 & $36.8 \mathrm{a}$ \\
\hline Mean & & $34.8 \mathrm{~b}$ & $36.2 \mathrm{a}$ & $36.4 \mathrm{a}$ & \\
\hline Control & & & & & $33.95 \mathrm{~b}$ \\
\hline Rest of treatments & & & & & $36.31 \mathrm{a}$ \\
\hline Hand weeding & & & & & $38.9 \mathrm{a}$ \\
\hline Herbicide & & & & & $36.2 \mathrm{~b}$ \\
\hline Herbicide sole & & & & & $39.94 \mathrm{a}$ \\
\hline Ratio & & & & & $35.81 \mathrm{~b}$ \\
\hline
\end{tabular}

${ }^{\dagger}$ Affinity recommended dose

$\mathrm{LSD}_{0.05}$ for concentration $\quad=1.39$

$\mathrm{LSD}_{0.05}$ for application time $\quad=1.39$

$\mathrm{LSD}_{0.05}$ for ratio $\quad=1.39$

Means within the same category followed by different letters are significantly different at $\mathrm{P} \leq 0.05$ using LSD test. 
Table 5.Economic analysis of sorghum extract concentrations with combination of herbicide application time

\begin{tabular}{|c|c|c|c|c|c|c|c|c|}
\hline Treatments & $\begin{array}{c}\text { Grain } \\
\text { yield } \\
\left(\mathrm{kg} \mathrm{ha}^{-1}\right)\end{array}$ & $\begin{array}{c}\text { Straw } \\
\text { yield (kg } \\
\left.\text { ha }^{-1}\right)\end{array}$ & $\begin{array}{c}\text { Grain } \\
\text { value } \\
\text { (Rs.) } \\
\end{array}$ & $\begin{array}{c}\text { Straw } \\
\text { value } \\
\text { (Rs.) } \\
\end{array}$ & $\begin{array}{c}\text { Gross } \\
\text { income } \\
(\mathbf{R s .}) \\
\end{array}$ & $\begin{array}{c}\text { Total } \\
\text { Expenditure }\end{array}$ & $\begin{array}{c}\text { Net } \\
\text { income }\end{array}$ & VCR \\
\hline Control & 2917 & 5700 & 93344 & 68400 & 161744 & 29000 & 132744 & 4.6 \\
\hline Hand weeding & 4016 & 6318 & 128512 & 75816 & 204328 & 31500 & 172828 & 5.5 \\
\hline Herbicide sole & 3556 & 5348 & 113792 & 64176 & 177968 & 30317 & 147651 & 4.9 \\
\hline \multicolumn{9}{|c|}{ Sorghum concentrations } \\
\hline $\mathrm{C} 1$ & 3384 & 6182 & 108288 & 74184 & 182472 & 32000 & 150472 & 4.7 \\
\hline $\mathrm{C} 2$ & 3438 & 6345 & 110016 & 76140 & 186156 & 32000 & 154156 & 4.8 \\
\hline $\mathrm{C} 3$ & 3727 & 6415 & 119264 & 76980 & 196244 & 32000 & 164244 & 5.1 \\
\hline \multicolumn{9}{|l|}{ Herbicide ratio } \\
\hline HB1 & 3379 & 6290 & 108128 & 75480 & 183608 & 29670 & 153938 & 5.2 \\
\hline HB2 & 3504 & 6504 & 112128 & 78048 & 190176 & 29988 & 160188 & 5.3 \\
\hline HB3 & 3665 & 6150 & 117280 & 73800 & 191080 & 30317 & 160763 & 5.3 \\
\hline \multicolumn{9}{|l|}{ Application time } \\
\hline AT1 & 3420 & 6403 & 109440 & 76836 & 186276 & 32670 & 153606 & 4.7 \\
\hline AT2 & 3616 & 6390 & 115712 & 76680 & 192392 & 32988 & 159404 & 4.8 \\
\hline AT3 & 3513 & 6150 & 112416 & 73800 & 186216 & 33317 & 152899 & 4.6 \\
\hline
\end{tabular}

Grain recent market price $=$ Rs. $32 \mathrm{~kg}^{-1}$

Straw recent market price $=\mathrm{Rs} .12 \mathrm{~kg}^{-1}$

Herbicide price (Affinity) $=800$ per $800 \mathrm{~g}$

Hand weeding $=500$ Rs. Person $^{-1}$ per day

\section{Conclusion}

It was concluded that the combination of sorghum water extract $1: 5$ and herbicide $1317 \mathrm{~g} \mathrm{ha}^{-1}(2 / 3)$ of the recommended dose of affinity applied at tillering stage significantly increased yield components and maximized net return of wheat crop.

\section{Authors' contributions}

Conceived and designed the experiments: SK Khalil \& A Tabassum, Performed the experiments: A Tabassum, Analyzed the data: A Tabassum, T Shah \& M Alamzeb, Contributed reagents/ materials/ analysis tools: Z Rahman, Misbahullah, S Khan, Tauheed, \& H Ali, Wrote the paper: A Tabassum \& SK Khalil.

\section{References}

1. Ozturk M, Kebapci U, Gucel E, Cetin E \& Altundag E (2012). Biodiversity and land degradation in the lower Euphrates sub region of Turkey. J Environ Biol 33: 311323.

2. Marwat KB, Muhammad S, Zahid H, Gul B $\&$ Rasheed H (2008). Study of various weed management for weed control in wheat under irrigated conditions. Pak J Weed Sci Res 14(1-2): 1-8.

3. Pandya N, Chouhan GS \& Nepalia V (2005). Effect of varieties, crop geometries and weed management on nutrient uptake by soybean (Glycine max) and associated weeds. Indian J Agron 50(3): 218-220.

4. Blair A, Zahir SH \& Pearce NE (1992). Clues to cancer etiology from studies of farmers. Environ Health 18: 205-209.

5. Nazarko OM, Van Acker RC, Entz MH, Scoofs A \& Martens G (2003). Pesticides free production of field crops: Results of an on-farm pilot project. Agron. J 95: 12621273.

6. Doug AD, Randy LA, Blackshaw RE \& Maxwell B (2002). Weeds dynamics and management strategies for cropping systems in Northern Great Plains. Agron J 94: 174185.

7. Ahmad S, Cheema ZA \& Mehmood A (1991). Response of some rabi weeds in wheat to allelopathic effects of irrigated sorghum in a sorghum wheat cropping systems. Pak J Weed Sci Res 4: 81-88.

8. Cheema ZA (1988). Weed control in wheat through sorghum allelochemicals. Ph.D. Thesis, Deptt of Agron, Univ of Agric Faisalabad, Pakistan.

9. Cheema ZA \& Khaliq A (2000). Use of sorghum allelopathic properties to control weeds in irrigated wheat in a semi-arid 
region of Punjab. Agric Ecosys Environ 79: 105-112.

10. Roth CM, Shroyer JP \& Paulsenice GM (2000). Allelopathy of sorghum on wheat under several tillage systems. Agron J 92: 855-860.

11. Suthep T, Kobayashi K \& Usui K (2001). Allelopathic activity of Mexican sunflower Tithonia diversifolia(Hems) A. Gray in soil under natural field conditions and different moisture conditions. Weed Biol Manag 1: 115-120.

12. Vyvyan JR (2002). Allelochemicals as leads for new herbicides and agrochemicals. Tetrahedron 58: 16311646.

13. Macias F, Varela RM, Torres A, Galindo JLG \& Molinilo JMG (2002). Allelochemicals from sunflowers: chemistry, bioactivity and applications. pp 73-87.

14. Bogatek R, Gniazdowska A, Zakrzewska W, Oracz K, Gawronski SW (2006). Allelopathic effects of sunflower extracts on mustard seed germination and seedling growth. Biol Plantarum 50: 156-158.

15. Kupidłowska E, Gniazdowska A, Stępień J, Corbineau F, Vinel D, Skoczowski A, Janeczko A \& Bogatek R (2006). Impact of Sunflower (Helianthus annuus L.) Extracts upon reserve mobilization and energy metabolism in germinating mustard (Sinapisalba L.) seeds. J Chem Ecol 32: 2569- 2583.

16. Oladejo JA \& Adetunji MO (2012). Economic analysis of maize (zea mays 1.) production in Oyo state of Nigeria. Agri Sci Res J 2(2): 77-83.

17. Jan MT, Shah P, Hollington PA, Khan MJ \& Sohail Q (2009). Agric Res Des Anal A Monograph. NWFP Agric Univ Pesh Pak.

18. Khan MH, Hassan G, Khan N \& Khan MA (2003). Efficacy of different herbicides for controlling broadleaf weeds in wheat. Asian J Plant Sci 2(3): 254-256.

19. Noor, K, Khan EA, Baloch MS, Khan MA, Ullah I, Sadiq M \& Aslam M (2012). Allelopathic effect of congress grass on weeds and yield of wheat. Pak J Weed Sci Res 18(3): 307-318.
20. Khan EA, Khakhwani AZ, Munir M \& Ullah G (2015). Effect of allelopathic chemicals extracted from various plant leaves on weeds control and wheat crop productivity. Pak J Bot 47 (2): 735-740.

21. Khan MA, Zahoor M, Ahmad L, Hassan G $\&$ Baloch MS (1999). Efficacy of different herbicides for controlling broad leaf weed in wheat. Pak J Biol Sci 2: 732-4.

22. Khan MA, Marwat KB, Hassan G \& Khan $N$ (2002). Impact of weed management in maize planted in night. Pak $J$ Weed Res 8(1-2): 57-62.

23. Cheema ZA, Khaliq A \& Ali K (2002). Efficacy of sorgaab for weed control in wheat grown at different fertility levels. Pak J Weed Sci Res 8(2): 33-39.

24. Nekonam MS, Razmjoo J, Sharifnabi B \& Hassan K (2013). Assessment of allelopathic plants for their herbicidal potential against field bindweed (Convolvulus arvensis). Aust J Crop Sci 7(11): 1654-1660.

25. Nauman M (1997). Allelopathic effects of sorghum and sunflower extract on growth and yield of wheat and certain rabi weeds. M.Sc. Thesis. Univ of Agric Faisalabad, Pakistan.

26. Hassan G, Faiz B, Marwat KB \& Khan M 2003). Effect of planting methods and tank mixed herbicides for controlling grassy and broad leaf weeds and their effect on wheat. Cv. Fakhre-Sarhad. Pak J Weed Sci Res 9(1-2): 1-11.

27. Marwat KB, Khan IA., Khan IM, Hussain Z \& Khan H (2005). Herbicides evaluation for weed control in chickpea. Pak J Weed Sci Res 11: 57-60.

28. Awan FK, Rasheed M, Ashraf M \& Khurshid MY (2012). Efficacy of brassica sorghum and sunflower aqueous extracts to control wheat weeds under rainfed conditions of Pothwar, Pak J Anim Plant Sci 22: 715-721.

29. Jamil M, Cheema ZA, Mushtaq MN, Farooq M \& Cheema MA (2009). Alternative control of wild oat and canary grass in wheat fields by allelopathic plant water extracts. Agron Sustain Dev 29: 475482. 